\title{
Elemental Composition, Antioxidant and Antibacterial Properties of Some Wild Edible Mushrooms from Romania
}

\author{
Melinda Fogarasi ${ }^{1}{ }^{(0)}$, Zorița Maria Diaconeasa ${ }^{2}{ }^{(0}$, Carmen Rodica Pop ${ }^{2}{ }^{(0}$, Szabolcs Fogarasi ${ }^{3}$, \\ Cristina Anamaria Semeniuc ${ }^{1} \mathbb{D}$, Anca Corina Fărcaş ${ }^{2} \mathbb{D}$, Dorin Țibulcă ${ }^{1, *}$, \\ Claudiu-Dan Sălăgean ${ }^{1}$, Maria Tofană ${ }^{2}$ (D) and Sonia Ancuța Socaci ${ }^{2, * \mathbb{D}}$ \\ 1 Department of Food Engineering, University of Agricultural Sciences and Veterinary Medicine of \\ Cluj-Napoca, Calea Mănăstur 3-5, 400372 Cluj-Napoca, Romania; melinda.fogarasi@usamvcluj.ro (M.F.); \\ cristina.semeniuc@usamvcluj.ro (C.A.S.); dan.salagean@usamvcluj.ro (C.-D.S.) \\ 2 Department of Food Science, University of Agricultural Sciences and Veterinary Medicine of Cluj-Napoca, \\ Calea Mănăștur 3-5, 400372 Cluj-Napoca, Romania; zorita.diaconeasa@gmail.com (Z.M.D.); \\ carmen-rodica.pop@usamvcluj.ro (C.R.P.); anca.farcas@usamvcluj.ro (A.C.F.); \\ maria.tofana@usamvcluj.ro (M.T.) \\ 3 Faculty of Chemistry and Chemical Engineering, Babeş-Bolyai University, 11 Arany Janos Str., \\ 400028 Cluj-Napoca, Romania; szabolcs.fogarasi@ubbcluj.ro \\ * Correspondence: dorin.tibulca@usamvcluj.ro (D.T.); sonia.socaci@usamvcluj.ro (S.A.S.); \\ Tel.: +40-264-596388 (S.A.S.); Fax: +40-264-593792 (S.A.S.)
}

Received: 13 November 2020; Accepted: 14 December 2020; Published: 15 December 2020

\begin{abstract}
Five selected wild edible mushrooms from Romania (Agaricus bisporus, Pleurotus ostreatus, Cantharellus cibarius, Boletus edulis, and Lactarius piperatus) were investigated for their antioxidant potential using an ABTS spectrophotometric assay. Among the selected mushrooms, B. edulis displayed the highest radical scavenging activity and the greatest phenolic content, measured by the Folin-Ciocalteu reagent method. The total flavonoids were quantified using the aluminum chloride colorimetric method, with the extract of B. edulis being the richest. L. piperatus and B. edulis mushrooms exhibited the strongest antibacterial activity against $S$. aureus and E. coli. The content of trace elements was determined using an atomic absorption spectrometer, and it was found that $\mathrm{K}$ and $\mathrm{Mg}$ were the main metals present in all the selected mushroom species. The obtained results suggest that the studied wild edible mushrooms are natural functional matrices, and may have potential to be used as natural antioxidants if they are introduced into the daily diet.
\end{abstract}

Keywords: antioxidant; antimicrobial properties; bioactive compounds; elemental composition; mushrooms

\section{Introduction}

Today, the attention of consumers is focused more and more on healthier and safer food products, rich in bioactive compounds that can provide the body's necessary nutrients, and the energy required for the modern lifestyle. For this reason, globally there can be witnessed a growing demand for functional foods due to significant changes in dietary habits [1].

In order to fulfill this modern necessity of a balanced diet, many researchers have pointed out the importance of plants and different food products fortified with vegetable sources, among which an important category is represented by edible mushrooms [2]. In consequence, edible mushrooms have received the attention of consumers because, in addition to the fact that they are tasty, they also possess remarkable nutritional value due to their high protein, carbohydrate, vitamin, and mineral content, as well as their associated low-fat content [3-5]. 
Due to their nutritional components, many researchers consider edible mushrooms as the next generation food, with potential benefits not only from a nutritional point of view but also from a medical one; considering that for their unique properties they could be used for the treatment of different diseases like tumors and nervous disorders [6,7]. In fact, edible mushrooms are characterized by antifungal, anti-inflammatory, antiviral, antibacterial, hepatoprotective, antidiabetic, hypolipidemic, hypotensive, and cytotoxic properties, as well as by a diversified composition, involving the presence of some relevant biomolecules, such as phenolic compounds, tocopherols, ascorbic acid, and proteins/enzymes [8-10]. Novel approaches in the bio-medical and biotechnological fields have appeared because mushrooms produce many bioactive peptides or proteins, such as lectins, fungal immunomodulatory proteins, antimicrobial proteins, ribonucleases, ribosome inactivating proteins, and ribotoxins [11,12]. Edible mushrooms also contain many traces and minor elements, like chromium, cobalt, copper, iron, manganese, and zinc which are essential for the development and function of the human body [13].

It is also important to note that, depending on climate and soil conditions, wild edible mushrooms could also have a negative effect on human health through the accumulation of toxic heavy metals like mercury, lead, cadmium, and organic substances resulting from human industrial activities [14].

Romania's mountains, such as the Carpathian Mountains, are recognized as a significant source of wild edible mushrooms for Europe, which could supply different species of wild edible mushrooms. However, despite their great potential, there have only been a few published studies regarding the bioactive compounds and antimicrobial activity of Transylvanian wild edible mushrooms $[4,13,15,16]$. Thus, in order to emphasize the potential benefits of some Transylvanian wild edible mushrooms, the present study aims to determine the antioxidant and antimicrobial activity, total phenolic and total flavonoid contents, and the elemental profile of the selected mushrooms species.

\section{Materials and Methods}

\subsection{Mushrooms Material and Preparation of Extracts}

Fruiting bodies of the selected mushroom species (Agaricus bisporus, Pleurotus ostreatus, Cantharellus cibarius, Boletus edulis, and Lactarius piperatus) were collected between September-November 2018, from Meseş Mountain, Sălaj County, Transylvania region, Romania. The clean fruiting bodies of the fresh mushrooms were dried at $45^{\circ} \mathrm{C}$ using a laboratory plant dryer, followed by their being ground (using a laboratory mill) into a fine powder. All the samples were kept at $4{ }^{\circ} \mathrm{C}$, for further analysis. The methanolic mushroom extracts were prepared as reported in a previous publication [17]. Briefly, the powdered material was extracted with methanol $(1: 10, w / v)$ until the extraction solvent became colorless (the total used solvent volume was $60 \mathrm{~mL}$ ). The obtained filtrates were dried at $40{ }^{\circ} \mathrm{C}$ with a vacuum rotary evaporator, and then redissolved in $8 \mathrm{~mL}$ of methanol and stored at $-20^{\circ} \mathrm{C}$ until analyzed.

\subsection{Total Phenolic Content}

The total phenolic content of each mushroom methanolic extract was quantified by a slightly modified Folin-Ciocalteu method, and expressed as mg of gallic acid equivalents (GAE)/100 g dry weight (DW) $[18,19]$. Briefly, an aliquot of the extract $(25 \mu \mathrm{L})$ was initially mixed with $1.8 \mathrm{~mL}$ of distilled water, followed by the addition and homogenization with $120 \mu \mathrm{L}$ of Folin-Ciocalteu reagent. Five minutes later, $340 \mu \mathrm{L}$ of $7.5 \% \mathrm{Na}_{2} \mathrm{CO}_{3}$ aqueous solution were added to the mixture. The samples were incubated for $90 \mathrm{~min}$ at room temperature in the dark, and then their absorbances were read at $750 \mathrm{~nm}$ against the blank, using a microplate reader (BioTek Instruments, Winooski, VT, USA). Each extract was analyzed in triplicate. 


\subsection{Total Flavonoid Content}

The content of total flavonoid of each methanolic mushroom extract was determined using an aluminum chloride colorimetric assay, as described previously in other studies [20]. Briefly, after the dilution of the methanolic extracts with distilled water to a final volume of $5 \mathrm{~mL}$, a volume of $300 \mu \mathrm{L} 5 \%$ $\mathrm{NaNO}_{2}$ was added. After $5 \mathrm{~min}$ incubation, $300 \mu \mathrm{L} \mathrm{AlCl}_{3}(10 \%)$ were added and then $2 \mathrm{~mL} \mathrm{NaOH} 1 \mathrm{M}$. The absorbance was recorded at $510 \mathrm{~nm}$ using a spectrophotometer (JASCO V-630 series, International Co., Ltd., Tokyo, Japan). The results were expressed as mg quercetin equivalents (QE)/100 $\mathrm{g}$ dry weight (DW). Each extract was analyzed in triplicate.

\subsection{ABTS Radical Cation Decolorization Assay $\left(\mathrm{ABTS}^{+}\right)$}

The antioxidant activity of the mushrooms extracts was determined according to the procedure described by Arnao et al. [21], with some modifications. The blue-green, $\mathrm{ABTS}^{+}$solution was prepared by mixing a $7 \mathrm{mM}$ aqueous solution of $\mathrm{ABTS}^{+}$and $2.45 \mathrm{mM}$ potassium persulfate. The reaction was carried out in the dark at room temperature for $12-16 \mathrm{~h}$ before use. $\mathrm{ABTS}^{+}$working solution was obtained by diluting the stock solution with ethanol, having the absorbance of $0.70 \pm 0.02 \mathrm{AU}$ at $734 \mathrm{~nm}$. After obtaining the working solution, $20 \mu \mathrm{L}$ Trolox at different concentrations of mushroom extracts were added to $170 \mu \mathrm{L} \mathrm{ABTS}{ }^{+}$solutions, incubated for $6 \mathrm{~min}$ at room temperature, in the dark, and the absorbance measured using a microplate reader. Results were expressed as $\mu \mathrm{mol}$ Trolox/100 g DW.

\subsection{Bacterial Strains}

The following microorganisms were tested: Salmonella typhimurium (ATCC 14028), Staphylococcus aureus (ATCC 49444), Pseudomonas aeruginosa (ATCC 27853), Escherichia coli (ATCC 25922), and Bacillus cereus (ATCC 11778) (Microbiologics Inc., St. Cloud, MN, USA).

Each strain was grown in $10 \mathrm{~mL}$ sterile nutrient broth at $37^{\circ} \mathrm{C}$ for $24 \mathrm{~h}$, except B. cereus, which was grown at $30^{\circ} \mathrm{C}$ for $24 \mathrm{~h}$. The purity of the inoculum was confirmed by microscopic examination of the Gram-stained smear. A loopful of inoculum was transferred onto selective medium: (i) XLD agar for S. typhimurium; (ii) Baird-Parker agar base supplemented with egg yolk tellurite emulsion for S. aureus; (iii) pseudomonas agar base supplemented with pseudomonas CFC selective agar supplement for P. aeruginosa; (iv) TBX agar for E. coli; and (v) MYP agar base supplemented with egg yolk emulsion and polymyxin B Sulphat for B. cereus (Oxoid Ltd., Basingstoke, Hampshire, UK). Plates were incubated for $24 \mathrm{~h}$ at $37^{\circ} \mathrm{C}$, and at $30^{\circ} \mathrm{C}$ for B. cereus. Several colonies were transferred to sterile saline solution $(8.5 \mathrm{~g} / \mathrm{L})$, and adjusted to match the turbidity of McFarland 0.5 standard $\left(1.5 \times 10^{6} \mathrm{CFU} / \mathrm{mL}\right)$ [22].

\subsection{Assessment of Antibacterial Activity of Mushrooms Extracts}

The mushroom extracts were assessed using the Kirby-Bauer disk diffusion method ( $9 \mathrm{~mm}$ sterile paper discs; ANTF-009-1K0, PRAT DUMAS, Couze-St-Front, France) [23]. Gentamicin was the positive control $(0.4 \mathrm{mg} / \mathrm{mL}$ in saline solution) while the extraction solvents were used as negatives. An aliquot $100 \mu \mathrm{L}$ of inoculum $\left(1.5 \times 10^{6} \mathrm{CFU} / \mathrm{mL}\right)$ was spread on a Mueller-Hinton agar plate (Sifin Diagnostics $\mathrm{GmbH}$, Berlin, Germany). A sterile paper disc was placed onto the surface of the agar media in the middle of a Petri dish, and $45 \mu \mathrm{L}$ of sample was pipetted. Aseptic conditions were maintained throughout the experiment. The plates were incubated for $24 \mathrm{~h}$ at $37 \pm 1^{\circ} \mathrm{C}$. Digital calipers were used to measure the diameter of the zone of inhibition (in $\mathrm{mm}$ ). Each extract was analyzed in triplicate.

\subsection{Determination of the Minimum Inhibitory Concentration (MIC)}

The MIC was determined using a resazurin microtiter plate based antibacterial assay [24]. Into the first well of a 96-well microtiter plate, $100 \mu \mathrm{L}$ sterile nutrient broth and $100 \mu \mathrm{L}$ sample were added. Serial 11-fold dilutions were performed by transferring $100 \mu \mathrm{L}$ from well to well (in a row). From the last well of the row, $100 \mu \mathrm{L}$ was discarded. To each well, $10 \mu \mathrm{L}$ of inoculum $\left(1.5 \times 10^{6} \mathrm{CFU} / \mathrm{mL}\right)$ was added. Gentamicin $(0.04 \mathrm{mg} / \mathrm{mL}$ in saline solution) was used as a positive control. For the negative 
control, the extraction solvent was used. Microplates were incubated for $20-22 \mathrm{~h}$ at $37^{\circ} \mathrm{C}$. To each well, $20 \mu \mathrm{L}$ resazurin aqueous solution $(0.2 \mathrm{mg} / \mathrm{mL})$ was added. Microplates were incubated for $2 \mathrm{~h}$ at $37^{\circ} \mathrm{C}$. Resazurin is a blue non-fluorescent dye that becomes pink and fluorescent when reduced to resorufin by oxidoreductases within viable cells [22]. The concentration that completely inhibited bacterial growth (MIC) was the concentration at which the blue color did not change into pink. Each extract was analyzed in triplicate.

\subsection{Determination of the Minimum Bactericidal Concentration (MBC)}

To determine minimum bactericidal concentration (MBC), solid culture medium Mueller-Hinton $(\mathrm{MH})$ agar (Sifin Diagnostics GmbH, Berlin, Germany) was used. Minimum bactericidal concentration was determined by plating $10 \mu \mathrm{L}$ of samples from wells, where no indicator color change was recorded, on nutrient agar medium. The MH plates were further incubated for $24 \mathrm{~h}$. The lowest concentration with no growth (no colony) was defined as the MBC. Three different biological replicates were performed for each plate, and all experiments were done in duplicate.

\subsection{Elemental Analysis}

Elemental analysis was performed using an atomic absorption spectrometer (AAS, Model AVANTA PM), equipped with a graphite furnace (Model GF3000) and a programmable automatic sample loader (auto-sampler, Model PAL3000), all from GBC Scientific Equipment, (Braeside, Australia). For measurement hollow cathode lamps, a deuterium arc lamp for background correction (Model P701), and pyrolytically coated graphite tubes (Model P301), all from Photron PTY Ltd. (Victoria, Australia) were also used. The graphite tubes were changed after 100 ignitions. Ultra-pure argon gas and recirculated cooled distilled water flowed through the furnace hoses. The instrument was operated at a lamp current, wavelength, and slit width specific to each element. The standards, ranged between 20 and $100 \mu \mathrm{g} / \mathrm{L}$, were automatically prepared and injected in the graphite furnace using the PAL3000 auto-sampler. A non-linear calibration curve was generated immediately before each measurement using the "concentration least squares" built-in method, an excellent correlation being obtained $(r=0.9990)$ for the 20 to $100 \mu \mathrm{g} / \mathrm{L}$ domain. Each sample was measured in triplicate. Before measurements, the received probes were mineralized in aqua regia by a microwave mineralization system, Speedwave TM MWS-2, Berghof, Germany.

\subsection{Statistical Analysis}

The statistical analysis of obtained data was carried out using Minitab statistical software (version 16.1.0; LEAD Technologies, Inc., Charlotte, NC, USA). The differences in results among different groups were determined using one-way ANOVA. Post-hoc pairwise comparisons were performed with Tukey's test at a 95\% confidence level $(p<0.05)$. Correlations among data were calculated using Pearson's correlation coefficient.

\section{Results}

\subsection{Total Phenolic Content of Mushrooms Extracts}

Several studies have emphasized that a diet rich in phenolics and other compounds with high antioxidant potential can reduce the risk of heart disease, and prevent degenerative diseases [25]. Rich sources of antioxidants are berries, vegetables, and also mushrooms. Moreover, mushrooms contain proteins, vitamin B, and almost all essential amino acids [26]. In this study the contents of bioactive compounds of the five most commonly consumed wild mushrooms were assessed. Total phenolic and flavonoid contents of the analyzed mushroom extracts are presented in Table 1. 
Table 1. Total phenolic content (TPC), total flavonoid content (TFC), and antioxidant activity (ABTS ${ }^{+}$) of the mushroom extracts.

\begin{tabular}{cccc}
\hline Mushroom Species & TPC $(\mathbf{m g}$ GAE/100 g DW) & TFC $(\mathbf{m g ~ Q E} / \mathbf{1 0 0} \mathbf{g}$ DW $)$ & ABTS $(\boldsymbol{\mu M}$ Trolox/g DW $)$ \\
\hline Agaricus bisporus & $408.57 \pm 0.02^{\mathrm{c}}$ & $40.56 \pm 0.05^{\mathrm{b}}$ & $18.38 \pm 0.01^{\mathrm{c}}$ \\
Pleurotus ostreatus & $519.22 \pm 0.04^{\mathrm{b}}$ & $30.69 \pm 0.00^{\mathrm{c}}$ & $27.17 \pm 0.00^{\mathrm{b}}$ \\
Cantharellus cibarius $^{\mathrm{c}}$ & $104.91 \pm 0.03^{\mathrm{e}}$ & $20.53 \pm 0.03^{\mathrm{d}}$ & $12.50 \pm 0.00^{\mathrm{d}}$ \\
Boletus edulis & $806.58 \pm 0.00^{\mathrm{a}}$ & $70.81 \pm 0.01^{\mathrm{a}}$ & $97.09 \pm 0.01^{\mathrm{a}}$ \\
Lactarius piperatus $^{\mathrm{a}}$ & $113.06 \pm 0.02^{\mathrm{d}}$ & $12.52 \pm 0.03^{\mathrm{e}}$ & $11.15 \pm 0.00^{\mathrm{e}}$ \\
\hline
\end{tabular}

Different letters in the same column indicate statistically significant differences at $p<0.05$ (Tukey's test).

The TPC among the studied species ranged from 104.91 to $806.58 \mathrm{mg} \mathrm{GAE} / 100 \mathrm{~g}$ DW. The highest content in phenolic compounds was identified in B. edulis (806.58 mg GAE/100 g DW), followed by P. ostreatus with $519.22 \mathrm{mg} \mathrm{GAE} / 100 \mathrm{~g} \mathrm{DW}$, while for two of the studied species, L. piperatus and C. cibarius, the TPC was around $100 \mathrm{mg}$ GAE/100 $\mathrm{g}$ DW. The obtained values are in agreement with recently published data, where for the methanolic extract of P. ostreatus an amount of $545.52 \pm 3.92 \mathrm{mg}$ GAE/100 g DW, was determined [27,28]. Barros et al. [29] evaluated the correlation between the antioxidant activity and the maturity of L. piperatus fruiting body. The authors found that there is a relation between the maturity stages of the fruiting bodies and the production of antioxidant compounds. Thus, the maturity stages where the fruiting bodies of L. piperatus presented immature spores (i.e., immature (cap closed) and mature (cap opened) with immature spores) exhibited a higher TPC and TFC [29]. Keles et al. assessed the TPC of the methanolic extract of A. bisporus at $402 \mathrm{mg} / 100 \mathrm{~g}$, but the values for B. edulis and L. piperatus TPC's (1277.5 mg/100 g and $334.22 \mathrm{mg} / 100 \mathrm{~g}$, respectively) were higher [30].

\subsection{Total Flavonoid Content}

Regarding the amount of total flavonoid, as shown in previously table, the richest extracts were those of the B. edulis (70.81 mg QE/100 $\mathrm{g}$ DW) and L. piperatus samples (12 mg QE/100 $\mathrm{g} \mathrm{DW})$. A. Robaszkiewicz et al. determined the concentration of phenolic, flavonoids, $\beta$-carotene, and lycopene of thirteen frequently consumed species of Polish mushrooms, including L. piperatus [26]. In their study, the concentration of flavonoids for L. piperatus was higher, namely $24 \mathrm{mg}$ QE/100 g DW, suggesting the fact that pedo-climatic factors may also influence the production of different classes of bioactive compounds.

\subsection{Antioxidant Activity of Mushroom Extracts}

The ability to scavenge the $\mathrm{ABTS}^{+}$cation radical ranged from to 97.09 to $11.15 \mu \mathrm{M}$ Trolox/g DW for the methanolic extracts analyzed. Other studies showed lower values for the antioxidant activity of mushroom extracts [27]. This fact could be due to the harvesting stage, climate, and soil, and also different chemical composition. Overall, of all extracts, B. edulis was the richest in phenolic and flavonoid, and also was more effective in inhibiting the free radicals. Thus, this species of wild edible mushroom may have potential to be used as natural antioxidants.

Correlation analysis was used to examine the relationships among the different variables (the total phenolic content, flavonoids content, and the antioxidant activity) measured for the mushroom extracts. As it can be seen from the Table 2, all these variables are strongly positively correlated. The correlation coefficient between the total flavonoids and antioxidant activity is higher than that between total phenolic compounds and antioxidant activity. As such, a large positive value (close to 1 ) indicates that the corresponding two variables have a tendency to increase simultaneously. 
Table 2. Cross-correlation between TPC, TFC, and antioxidant activity of mushrooms extracts.

\begin{tabular}{cccc}
\hline & TPC (mg GAE/100 g DW) & TFC (mg QE/100 g DW) & ABTS $^{+}(\mu$ M Trolox/g DW) \\
\hline TPC $($ mg GAE/100 g DW) & 1 & 0.9291 & 0.8780 \\
TFC (mg QE/100 g DW) & 0.9291 & 1 & 0.9231 \\
ABTS $^{+}(\mu \mathrm{M}$ Trolox/g DW) & 0.8780 & 0.9231 & 1 \\
\hline
\end{tabular}

\subsection{Antibacterial Activity of Mushrooms Extracts}

According to the results presented in Table 3, from the tested microorganisms, the largest zone of inhibition was found against E. coli (9.5-13.24 mm), followed by B. cereus (10.09-12.04 mm), P. aeruginosa $(8.75-11.98 \mathrm{~mm})$, S. aureus $(9.25-11.65 \mathrm{~mm})$, and S. typhimurium $(10-11.18 \mathrm{~mm})$.

Table 3. Antibacterial activity of mushroom extracts (zone of inhibition including the diameter of the paper disk, $\mathrm{mm}$ ).

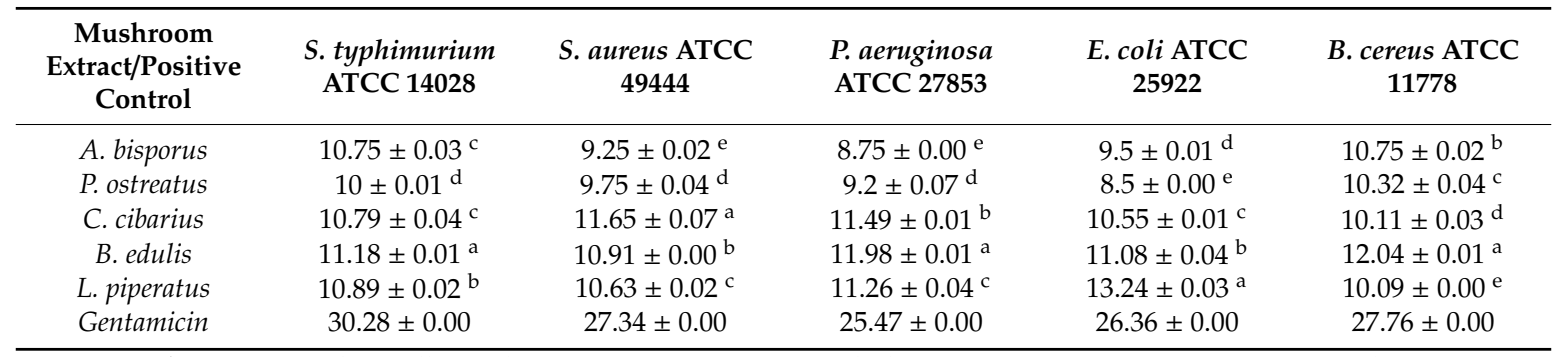

S. typhimurium-Salmonella typhimurium, S. aureus-Staphylococcus aureus, P. aeruginosa-Pseudomonas aeruginosa, E. coli-Escherichia coli, B. cereus-Bacillus cereus. Different letters in the same column indicate statistically significant differences at $p<0.05$ (Tukey's test).

Comparing the studied mushrooms species, it was found that L. piperatus showed the best antibacterial activity against $E$. coli $(13.24 \mathrm{~mm})$ and P. aeruginosa $(11.26 \mathrm{~mm})$, while B. edulis was best against $B$. cereus $(12.04 \mathrm{~mm})$ and $P$. aeruginosa $(11.98 \mathrm{~mm})$. A. bisporus had almost the same zones of inhibition against $S$. typhimurium and B. cereus $(10.75 \mathrm{~mm})$. On the other hand the results indicate that $P$. ostreatus and A. bisporus had similar inhibitory activity against all the tested microorganisms, which is in accordance with literature data [31].

\subsection{Minimum Inhibitory Concentrations (MICs) and Minimum Bactericidal Concentrations (MBCs)}

The obtained results regarding the MICs and MBCs of the studied mushrooms are summarized in Table 4. There was a strong positive correlation between values obtained using the two tests, since the MICs and MBCs were similar, except those of B. edulis and L. piperatus mushroom species against $S$. aureus and E. coli. It can be observed that the highest antibacterial activity was attributed to B. edulis mushroom species considering that it presented the lowest MIC/MBC value among the studied mushrooms.

Table 4. MICs and MBCs of mushroom extracts $(\mathrm{mg} / \mathrm{mL})$ against five different microorganisms by broth microdilution testing.

\begin{tabular}{|c|c|c|c|c|c|c|c|c|c|c|}
\hline \multirow{2}{*}{$\begin{array}{l}\text { Mushroom } \\
\text { Species }\end{array}$} & \multicolumn{2}{|c|}{$\begin{array}{l}\text { S. typhimurium } \\
\text { ATCC } 14028\end{array}$} & \multicolumn{2}{|c|}{$\begin{array}{c}\text { S. aureus } \\
\text { ATCC } 49444\end{array}$} & \multicolumn{2}{|c|}{$\begin{array}{l}\text { P. aeruginosa } \\
\text { ATCC } 27853\end{array}$} & \multicolumn{2}{|c|}{$\begin{array}{c}\text { E. coli } \\
\text { ATCC } 25922\end{array}$} & \multicolumn{2}{|c|}{$\begin{array}{c}\text { B. cereus } \\
\text { ATCC } 11778\end{array}$} \\
\hline & MIC & MBC & MIC & MBC & MIC & MBC & MIC & MBC & MIC & MBC \\
\hline A. bisporus & $59.52 \pm 0.00^{a}$ & $59.52 \pm 0.00^{a}$ & $59.52 \pm 0.00^{\mathrm{a}}$ & $59.52 \pm 0.00^{a}$ & $59.52 \pm 0.00^{a}$ & $59.52 \pm 0.00^{a}$ & $59.52 \pm 0.00^{\mathrm{a}}$ & $59.52 \pm 0.00^{a}$ & $59.52 \pm 0.00^{\mathrm{a}}$ & $59.52 \pm 0.00^{a}$ \\
\hline P. ostreatus & $59.52 \pm 0.00^{\mathrm{a}}$ & $59.52 \pm 0.00^{a}$ & $59.52 \pm 0.00^{\mathrm{a}}$ & $59.52 \pm 0.00^{a}$ & $59.52 \pm 0.00^{\mathrm{a}}$ & $59.52 \pm 0.00^{a}$ & $59.52 \pm 0.00^{\mathrm{a}}$ & $59.52 \pm 0.00^{a}$ & $59.52 \pm 0.00^{a}$ & $59.52 \pm 0.00^{\mathrm{a}}$ \\
\hline B. edulis & $28.34 \pm 0.00^{c}$ & $28.34 \pm 0.00^{c}$ & $13.49 \pm 0.00^{c}$ & $28.34 \pm 0.00^{c}$ & $28.34 \pm 0.00^{c}$ & $28.34 \pm 0.00^{c}$ & $13.49 \pm 0.00^{\mathrm{c}}$ & $28.34 \pm 0.00^{c}$ & $28.34 \pm 0.00^{c}$ & $28.34 \pm 0.00^{c}$ \\
\hline L. piperatus & $56.68 \pm 0.00^{\mathrm{b}}$ & $56.68 \pm 0.00^{\mathrm{b}}$ & $26.99 \pm 0.00^{\mathrm{b}}$ & $56.68 \pm 0.00^{\mathrm{b}}$ & $56.68 \pm 0.00^{\mathrm{b}}$ & $56.68 \pm 0.00^{\mathrm{b}}$ & $26.99 \pm 0.00^{\mathrm{b}}$ & $56.68 \pm 0.00^{\mathrm{b}}$ & $56.68 \pm 0.00^{\mathrm{b}}$ & $56.68 \pm 0.00^{b}$ \\
\hline
\end{tabular}

The results show that even if there were only slight differences, $L$. piperatus was the second most bacteriostatic after B. edulis against the five different microorganisms, providing the best performances 
against E. coli and S. aureus. Mushrooms of A. bisporus, P. ostreatus, and C. cibarius revealed similar bacteriostatic and bactericidal activities against S. typhimurium, S. aureus, P. aeruginosa, E. coli, and B. cereus.

\subsection{Elemental Analysis}

The concentrations of the elements quantified in the mushrooms from the Meses mountains are shown in Table 5. As was expected, regardless of the mushroom's species, potassium had the highest concentration among the identified metals, followed by $\mathrm{Mg}, \mathrm{Ca}$, and $\mathrm{Na}$. Among the studied mushrooms, L. piperatus had the highest potassium content, followed by A. bisporus, while the lowest $\mathrm{K}$ concentration was quantified in C. cibarius, being approximately $30 \%$ lower than in L. piperatus. According to the obtained experimental data Na content was the lowest in C. cibarius and the highest in L. piperatus, which contained almost twice as much $\mathrm{Na}$ than C. cibarius. Regarding the Mg content of the five mushrooms species, the results are in good correlation with the literature data, considering that B. edulis had the highest $\mathrm{Mg}$ content while A. bisporus had the lowest [13]. The most important difference in the elemental concentration of the mushroom extracts can be noticed in the case of calcium. Table 5 indicates that Ca content varied by $470 \%$ between the highest value found in P. ostreatus, and the lowest one obtained in the case of $A$. bisporus. In the case of the other elements identified in the mushroom extracts, the results revealed that $C$. cibarius had the highest $\mathrm{Cu}, \mathrm{Fe}$, and $\mathrm{Ba}$ concentrations, while B. edulis had the highest $\mathrm{Mn}$, and Co concentrations. Similarly, to calcium, an important divergence was found for Ba concentration which was seven times higher in $C$. cibarius compared to the lowest values measured in B. edulis. Chromium concentration was the highest in A. bisporus, however there were only slight differences in $\mathrm{Cr}$ content between the studied mushrooms species.

Table 5. Elemental concentration of mushroom extracts.

\begin{tabular}{|c|c|c|c|c|c|}
\hline \multirow{2}{*}{ Elements } & \multicolumn{5}{|c|}{ Concentration in Mushroom Species, mg/kg DW } \\
\hline & A. bisporus & P. ostreatus & C. cibarius & B. edulis & L. piperatus \\
\hline $\mathrm{Cu}$ & $30.20 \pm 0.05^{c}$ & $13.28 \pm 0.09^{\mathrm{e}}$ & $49.20 \pm 0.08^{a}$ & $32.41 \pm 0.01^{\mathrm{b}}$ & $27.27 \pm 0.02^{\mathrm{d}}$ \\
\hline $\mathrm{Fe}$ & $73.82 \pm 0.07^{\mathrm{e}}$ & $91.30 \pm 1.00^{c}$ & $165.50 \pm 0.00^{\mathrm{a}}$ & $105.17 \pm 0.02^{b}$ & $85.38 \pm 0.09^{d}$ \\
\hline $\mathrm{Mn}$ & $14.79 \pm 0.04^{\mathrm{e}}$ & $25.40 \pm 0.02^{\mathrm{d}}$ & $28.43 \pm 0.03^{c}$ & $60.84 \pm 0.00^{a}$ & $35.71 \pm 0.02^{b}$ \\
\hline $\mathrm{Cr}$ & $0.85 \pm 0.01^{\mathrm{a}}$ & $0.76 \pm 0.02^{b}$ & $0.44 \pm 0.00^{\mathrm{e}}$ & $0.69 \pm 0.01^{\mathrm{c}}$ & $0.66 \pm 0.01^{d}$ \\
\hline $\mathrm{Ba}$ & $0.29 \pm 0.03^{c}$ & $0.20 \pm 0.02^{\mathrm{d}}$ & $1.00 \pm 0.01^{\mathrm{a}}$ & $0.14 \pm 0.02^{\mathrm{e}}$ & $0.45 \pm 0.01^{b}$ \\
\hline $\mathrm{Co}$ & $0.13 \pm 0.01^{c}$ & $0.07 \pm 0.02^{\mathrm{d}}$ & $0.24 \pm 0.03^{b}$ & $0.32 \pm 0.01^{\mathrm{a}}$ & $0.32 \pm 0.04^{\mathrm{a}}$ \\
\hline $\mathrm{Zn}$ & $85.24 \pm 0.01^{\mathrm{e}}$ & $127.33 \pm 0.02^{c}$ & $149.14 \pm 0.02^{b}$ & $163.26 \pm 0.02^{a}$ & $91.40 \pm 0.03^{\mathrm{d}}$ \\
\hline $\mathrm{Ca}$ & $127.33 \pm 0.25^{\mathrm{e}}$ & $725.40 \pm 0.17^{a}$ & $530.40 \pm 0.26^{b}$ & $451.23 \pm 0.12^{c}$ & $347.60 \pm 0.30^{\mathrm{d}}$ \\
\hline $\mathrm{Mg}$ & $598.33 \pm 0.25^{\mathrm{e}}$ & $803.33 \pm 0.23^{c}$ & $810.47 \pm 0.38^{b}$ & $998.23 \pm 0.15^{a}$ & $752.33 \pm 0.12^{d}$ \\
\hline $\mathrm{Na}$ & $151.10 \pm 0.00^{c}$ & $149.23 \pm 0.15^{\mathrm{d}}$ & $120.60 \pm 0.30^{\mathrm{e}}$ & $176.40 \pm 0.44^{b}$ & $217.27 \pm 0.12^{\mathrm{a}}$ \\
\hline K & $26640.40 \pm 0.20^{b}$ & $25600.40 \pm 0.35^{c}$ & $21260.23 \pm 0.06^{\mathrm{e}}$ & $23802.40 \pm 0.26^{\mathrm{d}}$ & $29118.53 \pm 0.29^{a}$ \\
\hline
\end{tabular}

\section{Conclusions}

The current paper provides an evaluation of the antioxidant and antimicrobial activities and elemental composition of different Transylvanian wild edible mushrooms. The experimental results revealed that regardless of the mushrooms species, potassium had the highest concentration among the identified metals followed by $\mathrm{Mg}, \mathrm{Ca}$, and $\mathrm{Na}$. However, in terms of total phenolic compounds, flavonoid content, and antioxidant activity B. edulis greatly outperformed the other mushroom species. Similar conclusions can be drawn regarding the antibacterial activity of the mushroom extracts, considering that B. edulis had the largest zone of inhibition against the tested microorganisms, followed by $L$. piperatus. It was also found that B. edulis had the lowest MIC and MBC values, having the highest antibacterial activity, followed by L. piperatus, which was slightly better than the other three mushroom species. As an overall conclusion it can be stated that among the studied mushroom species B. edulis has the greatest potential to be used as a natural source of bioactive compounds for the production of functional foods. 
Author Contributions: Conceptualization, S.A.S., M.F. and D.T.; methodology, S.A.S. and M.T.; formal analysis, M.F., A.C.F., S.A.S. and C.A.S.; investigation, S.A.S., Z.M.D., C.-D.S. and C.R.P.; writing-original draft preparation, M.F. and S.F.; writing-review and editing, M.F., S.A.S. and M.T.; supervision, S.A.S.; project administration, M.F. and A.C.F.; funding acquisition, M.F. and A.C.F. All authors have read and agreed to the published version of the manuscript.

Funding: This work was supported by two grants of Ministry of Research and Innovation, CNCS-UEFISCDI, project number PN-III-P1-1.1-PD-2019-0475 and project number PN-III-P2-2.1-PED-2019-3622, within PNCDI III.

Acknowledgments: We are grateful for the administrative and financial support offered by the University of Agricultural Sciences and Veterinary Medicine Cluj-Napoca and Babes-Bolyai University, Romania.

Conflicts of Interest: The authors declare no conflict of interest.

\section{References}

1. Martins, N.; Ferreira, I.C.F.R. Mountain food products: A broad spectrum of market potential to be exploited. Trends Food Sci. Technol. 2017, 67, 12-18. [CrossRef]

2. Reis, F.S.; Martins, A.; Vasconcelos, M.H.; Morales, P.; Ferreira, I.C.F.R. Functional foods based on extracts or compounds derived from mushrooms. Trends Food Sci. Technol. 2017, 66, 48-62. [CrossRef]

3. Islam, T.; Yu, X.; Xu, B. Phenolic profiles, antioxidant capacities and metal chelating ability of edible mushrooms commonly consumed in China. LWT-Food Sci. Technol. 2016, 72, 423-431. [CrossRef]

4. Fogarasi, M.; Socaci, S.A.; Dulf, F.V.; Diaconeasa, Z.M.; Farcas, A.C.; Tofana, M.; Semeniuc, C.A. Bioactive Compounds and Volatile Profiles of Five Transylvanian Wild Edible Mushrooms. Molecules 2018, 23, 3272. [CrossRef]

5. Bekiaris, G.; Tagkouli, D.; Koutrotsios, G.; Kalogeropoulos, N.; Zervakis, G.I. Pleurotus Mushrooms Content in Glucans and Ergosterol Assessed by ATR-FTIR Spectroscopy and Multivariate Analysis. Foods 2020, 9, 535. [CrossRef]

6. Rathore, H.; Prasad, S.; Sharma, S. Mushroom nutraceuticals for improved nutrition and better human health: A review. PharmaNutrition 2017, 5, 35-46. [CrossRef]

7. Leong, Y.K.; Yang, F.-C.; Chang, J.-S. Extraction of polysaccharides from edible mushrooms: Emerging technologies and recent advances. Carbohydr. Polym. 2021, 251, 117006. [CrossRef]

8. Aprotosoaie, A.C.; Zavastin, D.E.; Mihai, C.T.; Voichita, G.; Gherghel, D.; Silion, M.; Trifan, A.; Miron, A. Antioxidant and antigenotoxic potential of Ramaria largentii Marr \& D. E. Stuntz, a wild edible mushroom collected from Northeast Romania. Food Chem. Toxicol. Int. J. Publ. Br. Ind. Biol. Res. Assoc. 2017, 108, 429-437. [CrossRef]

9. Piskov, S.; Timchenko, L.; Grimm, W.D.; Rzhepakovsky, I.; Avanesyan, S.; Sizonenko, M.; Kurchenko, V. Effects of Various Drying Methods on Some Physico-Chemical Properties and the Antioxidant Profile and ACE Inhibition Activity of Oyster Mushrooms (Pleurotus Ostreatus). Foods 2020, 9, 160. [CrossRef]

10. Ragucci, S.; Pacifico, S.; Ruocco, M.R.; Crescente, G.; Nasso, R.; Simonetti, M.; Masullo, M.; Piccolella, S.; Pedone, P.V.; Landi, N.; et al. Ageritin from poplar mushrooms: Scale-up purification and cytotoxicity towards undifferentiated and differentiated SH-SY5Y cells. Food Funct. 2019, 10, 6342-6350. [CrossRef]

11. Citores, L.; Ragucci, S.; Ferreras, J.M.; Di Maro, A.; Iglesias, R. Ageritin, a Ribotoxin from Poplar Mushroom (Agrocybe aegerita) with Defensive and Antiproliferative Activities. ACS Chem. Biol. 2019, 14, 1319-1327. [CrossRef]

12. Landi, N.; Ragucci, S.; Russo, R.; Valletta, M.; Pizzo, E.; Ferreras, J.M.; Di Maro, A. The ribotoxin-like protein Ostreatin from Pleurotus ostreatus fruiting bodies: Confirmation of a novel ribonuclease family expressed in basidiomycetes. Int. J. Biol. Macromol. 2020, 161, 1329-1336. [CrossRef] [PubMed]

13. Zsigmond, A.R.; Varga, K.; Harangi, S.; Baranyai, E.; Urák, I. Elemental profile of edible mushrooms from a forest near a major Romanian city. Acta Univ. Sapientiae Agric. Environ. 2015, 7, 98-107. [CrossRef]

14. Zsigmond, A.R.; Kantor, I.; May, Z.; Urak, I.; Heberger, K. Elemental composition of Russula cyanoxantha along an urbanization gradient in Cluj-Napoca (Romania). Chemosphere 2020, 238, 124566. [CrossRef] [PubMed]

15. Vamanu, E.; Nita, S. Antioxidant capacity and the correlation with major phenolic compounds, anthocyanin, and tocopherol content in various extracts from the wild edible Boletus edulis mushroom. Biomed Res. Int. 2013, 2013, 313905. [CrossRef] [PubMed] 
16. Gabriela Popa, G.; Nicolcioiu, M.B.; Ciuca, M.; Cornea, C.P. Studies concerning the in vitro cultivation of some indigenous macromycete species. Sci. Bulletin. Ser. F Biotechnol. 2014, XVIII, 54-59.

17. Mureşan, E.A.; Muste, S.; Borşa, A.; Sconţa, Z.; Crainic, D.; Mureşan, V. Total phenolic content changes during apple growth as a function of variety and fruit position in the crown. J. Agroaliment. Process. Technol. 2012, 18, 341-344.

18. Singleton, V.L.; Orthofer, R.; Lamuela-Raventós, R.M.; Lester, P. Analysis of total phenols and other oxidation substrates and antioxidants by means of Folin-Ciocalteu reagent. Method Enzym. 1999, 299, 152-178.

19. Farcas, A.; Socaci, S.; Tofana, M.; Mudura, E.; Salanta, L. The Content in Bioactive Compounds of Different Brewers' Spent Grain Aqueous Extracts. Bull. Univ. Agric. Sci. Vet. Med. Cluj-Napoca. Food Sci. Technol. 2016, 73, 143. [CrossRef]

20. Kim, D.-O.; Jeong, S.W.; Lee, C.Y. Antioxidant capacity of phenolic phytochemicals from various cultivars of plums. Food Chem. 2003, 81, 321-326. [CrossRef]

21. Arnao, M.B.; Cano, A.; Alcolea, J.F.; Acosta, M. Estimation of free radical-quenching activity of leaf pigment extracts. Phytochem. Anal. PCA 2001, 12, 138-143. [CrossRef] [PubMed]

22. Semeniuc, C.A.; Pop, C.R.; Rotar, A.M. Antibacterial activity and interactions of plant essential oil combinations against Gram-positive and Gram-negative bacteria. J. Food Drug Anal. 2017, 25, 403-408. [CrossRef]

23. Pop, A.V.; Tofană, M.; Socaci, S.A.; Pop, C.; Rotar, A.M.; Nagy, M.; Salanţă, L. Determination of Antioxidant Capacity and Antimicrobial Activity of Selected Salvia Species. Bull. Univ. Agric. Sci. Vet. Med. Cluj-Napoca. Food Sci. Technol. 2016, 73, 14-18. [CrossRef]

24. Semeniuc, C.A.; Socaciu, M.I.; Socaci, S.A.; Muresan, V.; Fogarasi, M.; Rotar, A.M. Chemometric Comparison and Classification of Some Essential Oils Extracted from Plants Belonging to Apiaceae and Lamiaceae Families Based on Their Chemical Composition and Biological Activities. Molecules 2018, 23, 2261. [CrossRef] [PubMed]

25. De Pascual-Teresa, S.; Moreno, D.A.; Garcia-Viguera, C. Flavanols and anthocyanins in cardiovascular health: A review of current evidence. Int. J. Mol. Sci. 2010, 11, 1679-1703. [CrossRef] [PubMed]

26. Kaur, K.; Verma, R.K. Chapter 2-Fungal resources: Current utilization, future prospects, and challenges. In New and Future Developments in Microbial Biotechnology and Bioengineering; Singh, J., Gehlot, P., Eds.; Elsevier: Amsterdam, The Netherlands, 2021; pp. 15-38. [CrossRef]

27. Robaszkiewicz, A.; Bartosz, G.; Lawrynowicz, M.; Soszynski, M. The role of polyphenols, beta-carotene, and lycopene in the antioxidative action of the extracts of dried, edible mushrooms. J. Nutr. Metab. 2010, 2010, 173274. [CrossRef] [PubMed]

28. Yim, H.S.; Chye, F.Y.; Ho, S.K.; Ho, C.W. Phenolic profiles of selected edible wild mushrooms as affected by extraction solvent, time and temperature. Asian J. Food Agro-Ind. 2009, 2, 392-401.

29. Barros, L.; Baptista, P.; Ferreira, I.C.F.R. Effect of Lactarius piperatus fruiting body maturity stage on antioxidant activity measured by several biochemical assays. Food Chem. Toxicol. 2007, 45, 1731-1737. [CrossRef]

30. Keleş, A.; Koca, İ.; Gençcelep, H. Antioxidant properties of wild edible mushrooms. J. Food Process. Technol. 2011, 2, 2-6. [CrossRef]

31. Smolskaitè, L.; Venskutonis, P.R.; Talou, T. Comprehensive evaluation of antioxidant and antimicrobial properties of different mushroom species. LWT-Food Sci. Technol. 2015, 60, 462-471. [CrossRef]

Publisher's Note: MDPI stays neutral with regard to jurisdictional claims in published maps and institutional affiliations.

(C) 2020 by the authors. Licensee MDPI, Basel, Switzerland. This article is an open access article distributed under the terms and conditions of the Creative Commons Attribution (CC BY) license (http://creativecommons.org/licenses/by/4.0/). 